\title{
Application of Holt-Winters Time Series Models for Predicting Climatic Parameters (Case Study: Robat Garah-Bil Station, Iran)
}

\author{
Mohammad Heydari ${ }^{1}$, Hamed Benisi Ghadim ${ }^{2 *}$, \\ Mahmood Rashidi ${ }^{3}$, Mohammad Noori ${ }^{4}$ \\ ${ }^{1}$ Department of Civil Engineering, University of Malaya, Kuala Lumpur, Malaysia \\ ${ }^{2}$ Department of Water Resources and Harbor Engineering, Faculty of Civil Engineering, Fuzhou University, \\ Fuzhou-Minhou, China \\ ${ }^{3}$ Department of Civil Engineering, Tabriz University, Tabriz, Iran \\ ${ }^{4}$ Department of Water Engineering, Gorgan University of Agricultural Sciences and Natural Resources
}

Received: 21 September 2018

Accepted: 4 December 2018

\begin{abstract}
Predicting hydrological variables is a very useful tool in water resource management. The importance of the forecast in environmental issues causes us to use more accurate statistical methods for studying the weather and climate change. The main objective of this study is to investigate the use of additive and multiplicative forms of the Holt-Winters time series model to predict environmental variables such as temperature, precipitation, and sunshine hours for one year in advance. As the Holt-Winters model uses a weighted average of current and past values to provide predictions, in this study higher emphasis is placed on the recent observations by using larger weights for these data compared to the older ones. As a case study, monthly environmental data (i.e., precipitation, maximum temperature, minimum temperature and sunshine hours) collected for a span of 30 years (from 1981 to 2010) from Robat Gharah-BilStation located in Golestan, Iran was used. After modeling the data through additive and multiplicative procedures, the main three smoothing parameters of the model are optimized using a nonlinear optimization method. Based on this study, using the multiplicative form of Holt-Winters time series results in an overall of $4 \%$ less mean absolute percentage error (MAPE) compared to the additive one. The result showed that this model is more efficient in predicting and modeling climate parameters, which show stable patterns of cycle and seasonality.
\end{abstract}

Keywords: time series, Holt-Winters's model, rainfall, temperature, sunshine hours

*e-mail: hbghadim@yahoo.com, haslinbeni@gmail.com 


\section{Introduction}

Predicted weather conditions in the future play a significant role in the decision-making process of many organizations [1-2]. In order to predict future events, we need to rely on information that is obtained from past events. In recent years, time-series analysis has been widely used for predicting environmental events [3-6]. A set of time series are the data collected at regular equal intervals, and statistical methods used to analyze these data are called time series analyzing.

\section{The Importance of Rainfall Prediction}

Limited water resources for agricultural and industrial water supply requirements, drinking and alike have caused major problems - particularly in arid and semi-arid areas. Therefore forecast and estimate of rainfall for each catchment area are one of the most important climatic parameters in order to use water resources efficiently [7-10]. Measurement and prediction of rainfall runoff to study runoff, sediment, groundwater, and flood is required generally [11-12]. Furthermore, prediction of precipitation for any watershed area is considered one of the most important climatic parameters for optimal use of water resources [13-14].

\section{The Importance of Temperature Prediction}

Due to climate change, global warming and recent droughts, temperature prediction and maximum temperature are some of the most important climate parameters that provide an opportunity to plan and,in the meantime, give planners appropriate schemes [15]. Analysis of maximum temperatures as one of the climate parameters in water and natural resources management [16], agriculture [17-18], spread of pests and diseases [19-21], snowmelt and runoff [22-24], evapotranspiration [25-28], and drought [29-31], etc., is crucial.

\section{The Importance of Solar Radiation Prediction}

Solar radiation is a meteorological variable that affects many processes, such as water and soil evaporation [32-33], snowmelt [34-35] and plant growth [36]. The Food and Agriculture Organization of the United Nations (FAO) has reported that having the exact amount of solar radiation is necessary for estimating potential evapotranspiration [37]. Due to large differences of latitude in Iran, solar radiation has considerable differences across the country [38-39].

The use of time series in hydrology started four decades ago and has reached the height by BUX and JENKINZ models. One of the first important studies on the use of time series in hydrology was done by McKerchar and Delleur [40], which due to the characteristics of the seasonal parameters of river flow, the ARIMA model (which is multiplicative and seasonal) was chosen to simulate the river. Many researchers have used time-series for predicting processes in their studies. Tiba et al. [41] used an AR-1 model for investigating monthly sunshine hours and solar radiation in tropical climates, i.e., Brazil. Komornik et al. [42] used hydrological time series models to be effective in predicting hydrological variables in the Czech Republic. Chatupadhyay [43] predicted seasonal precipitation in India by using the multilayer perceptron model in a neural network. Damle and Yalcin [44] predicted flooding by using time series in the Mississippi River in America. Their results show the ability of time series in constructing the daily discharge data and accuracy of the resulting predictions. Sunyer et al. [45] estimated the probability of dry and wet days based on future time series of daily precipitation using five different statistical down scaling methods. Noori et al. [46] used the LARS-WG to model of meteorological parameters such as rainfall, temperature and sunhours.

In recent years, researchers have studied the interaction of climate change on water resource issues in different parameters such as agriculture [47-48], water resources [49-50], urban water management [5152], erosion control [53], ecosystems and environmental issues [54-55], and water supply and demand [56].

All aforementioned and recent studies, however, have tried to simulate the main climate parameters such as precipitation and temperature to study the pattern of the related time series. Additionally, they try to present a future pattern of these parameters using several predicting methods. Therefore, the main purpose of this research is to apply the additive and multiplicative Holt-Winters model to predict the four climate parameters (maximum temperature, minimum temperature, rainfall and sunshine hours) for one consecutive year.

\section{Materials and Methods}

\section{Study Area}

Golestan Province with an area of over $20,387 \mathrm{~km}^{2}$ is located in northeast of Iran. Rabat Gharah-Bil Station is southeast of Gorgan-Rood basin. It has a semi-arid climate with an average annual rainfall of $350 \mathrm{~mm}$ and medium annual temperature of $18^{\circ} \mathrm{C}$. Rabat Gharebill Station is positioned at 21 degrees 37 minutes 12 seconds north latitude and 19 degrees 56 minutes 18 seconds east longitude, and is $1450 \mathrm{~m}$ a.s.l.

\section{Materials}

In this study, the maximum temperature, minimum temperature, rainfall and sunshine hours are utilized as parameters from the beginning of 1981 to the end of 2010. Data of average temperature, average minimum temperature, average rainfall, and average sunshine hours are given in Table 1. 


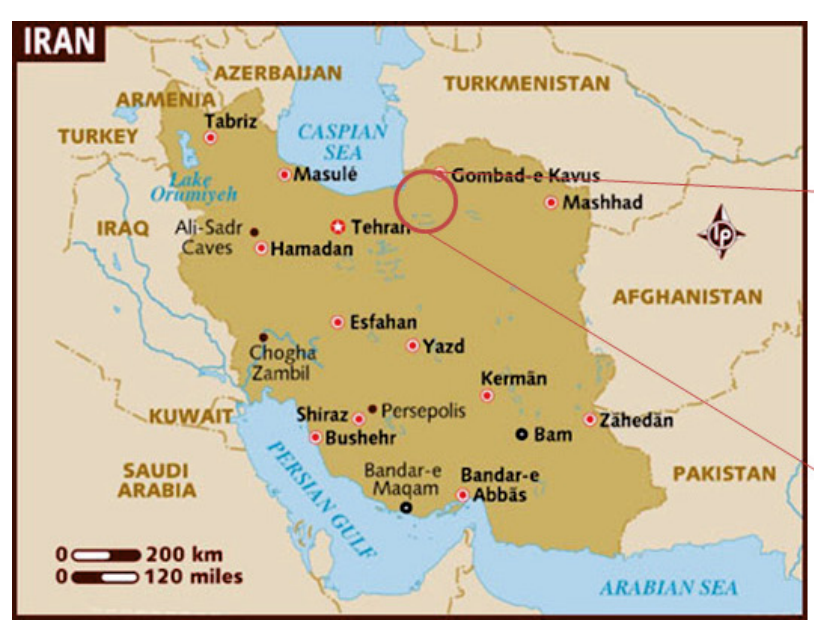

Fig. 1. Case study location (Rabat Gharah-Bil Station, Golestan Province): a) Maximum temperature $\left({ }^{\circ} \mathrm{C}\right)$, b) Minimum temperature $\left({ }^{\circ} \mathrm{C}\right)$, c) Rainfall (cm), d) sunshinehours(average hours per day).

\section{Methods}

\section{Holt-Winters Forecasting Method}

This prediction method is based on weighted average of past and present observations. In this method larger weights are used for more recent data to increase the significance of these data compared to the older data. In such a particular type of average, the heaviest weight is given to the most recent observation, and the lesser weights are given to previous observations. Afterward, estimation of level, procedure and seasonal index are required. Weather forecasting in Holt-Winters acquires the estimation of elements of average, procedure and seasonal index.
Holt-Winters's method can be developed to deal with time series that include trend and seasonal variations. This method has two versions: additive and multiplicative. The default of this method is multiplicative, which is the following function:

$\hat{y}_{n+1 \mid n}=\left(m_{n}+l b_{n}\right) c_{n-s+1} \quad l=1,2, \ldots$

...where $m_{n}$ is a part of the level, $b_{n}$ is a component of the slope, and $c_{n-s+1}$ is the relevant seasonal part (for example, 4 is for the season and 12 is for the month). Therefore, if the monthly time series are considered, one-step-ahead predictions are:

Table 1. Average maximum temperature, average minimum temperature, average rainfall and mean of sunshine hours (Maraveh Station Hill).

\begin{tabular}{|c|c|c|c|c|}
\hline Month & Average of Minimum Temperature & Average of Maximum Temperature & Average of Rainfall & Average of Sunny Hours \\
\hline Jan & -8.2 & 8.45 & 7.2 & 4.97 \\
\hline Feb & -6.87 & 9.57 & 31.5 & 5.58 \\
\hline Mar & -2.28 & 14.23 & 31.7 & 5.65 \\
\hline Apr & 3.09 & 21.1 & 29.0 & 6.36 \\
\hline May & 6.9 & 26.46 & 22.6 & 8.56 \\
\hline Jun & 11.16 & 31.29 & 8.3 & 9.89 \\
\hline Jul & 12.94 & 32.9 & 21.4 & 9.73 \\
\hline Aug & 12.26 & 23.15 & 5.5 & 10.02 \\
\hline Sep & 8.98 & 29.79 & 4.9 & 9.12 \\
\hline Oct & 3.84 & 23.58 & 10.5 & 7.8 \\
\hline Nov & -1.37 & 16.86 & 17.6 & 5.66 \\
\hline Dec & -5.29 & 11.17 & 17.4 & 5.03 \\
\hline $\begin{array}{c}\text { Annual } \\
\text { Mean }\end{array}$ & 2.93 & 20.71 & & 7.36 \\
\hline
\end{tabular}




$$
\hat{y}_{n+1 \mid n}=\left(m_{n}+b_{n}\right) c_{n-11}
$$

Updating formula for each component requires a smoothing constant. Considering, and to be parameters of level, slope and smoothing constant respectively, then the updated equations will change to:

$$
\begin{gathered}
m_{t}=\alpha \frac{y_{t}}{c_{t-s}}+(1-\alpha)\left(m_{t-1}-b_{t-1}\right) \\
b_{t}=\beta\left(m_{t}-m_{t-1}\right)+(1-\beta) b_{t-1} \\
c_{t}=\gamma \frac{y_{t}}{m_{t}}+(1-\gamma) c_{t-s}
\end{gathered}
$$

...where $\alpha, \beta$ and $\gamma$ are all between zero and one. If the additive version of Holt-Winters is used, then the seasonal factor is simply used as opposed to multiplying into the one-step-ahead forecast function, so:

$$
\hat{y}_{n+1 \mid n}=m_{n}+b_{n}+c_{n-11}
$$

The level and the updating equations of the seasonal include differences as opposed to ratios:

$$
\begin{gathered}
m_{t}=\alpha\left(y_{t}-c_{t-s}\right)+(1-\alpha)\left(m_{t-1}+b_{t-1}\right) \\
b_{t}=\beta\left(m_{t}-m_{t-1}\right)+(1-\beta) b_{t-1} \\
c_{t}=\gamma\left(y_{t}-m_{t}\right)+(1-\gamma) c_{t-s}
\end{gathered}
$$

Selecting proper smoothing parameters and initial values are important, Chatfield and Yar in 1988 discussed in this field [57]. It seems for initial values it is better to replace the $\mathrm{m}_{0}$ parameter with medium observations in the first year (for example), which means:

$$
m_{0}=\sum_{t=1}^{s} y_{t} / s
$$

...where $\mathrm{s}$ is the number of seasons. The initial value for the slope parameter is obtained by averaging the rate of variations from the first year to the second. a)

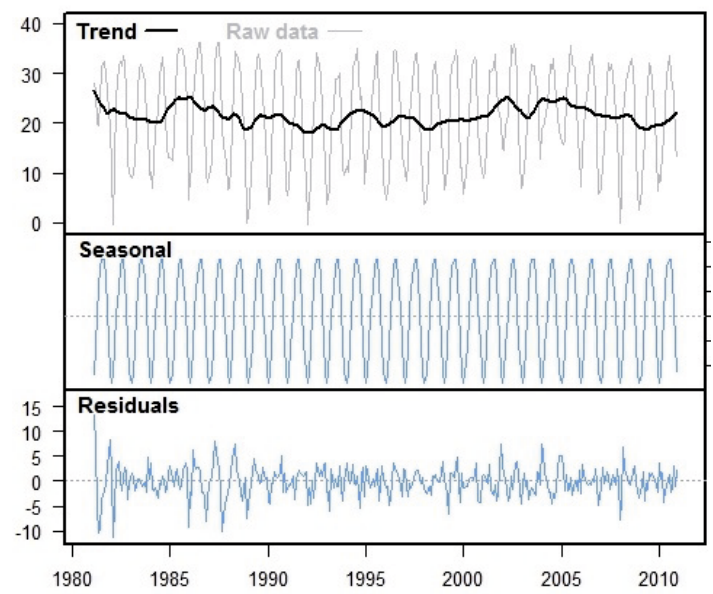

b)

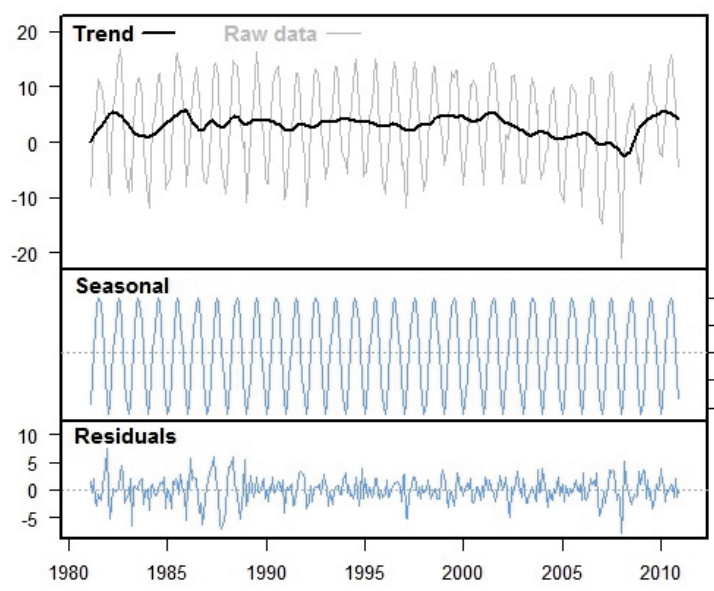

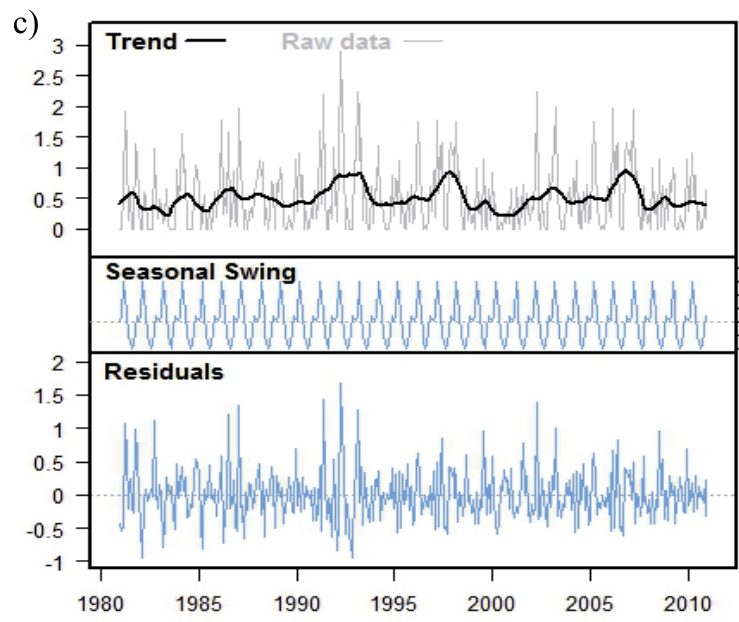

d)

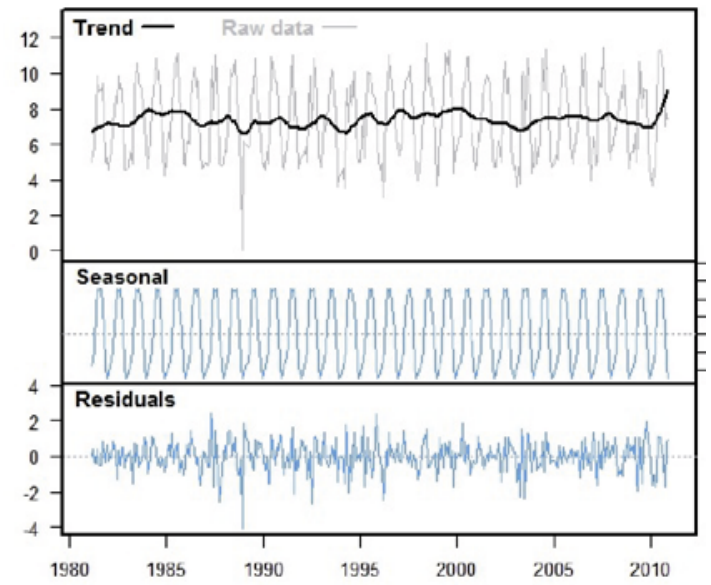

Fig. 2. Decomposition of seasonal variations and irregular variations for a) maximum temperature, b) minimum temperature, c) rainfall and d) sunshine hours. 


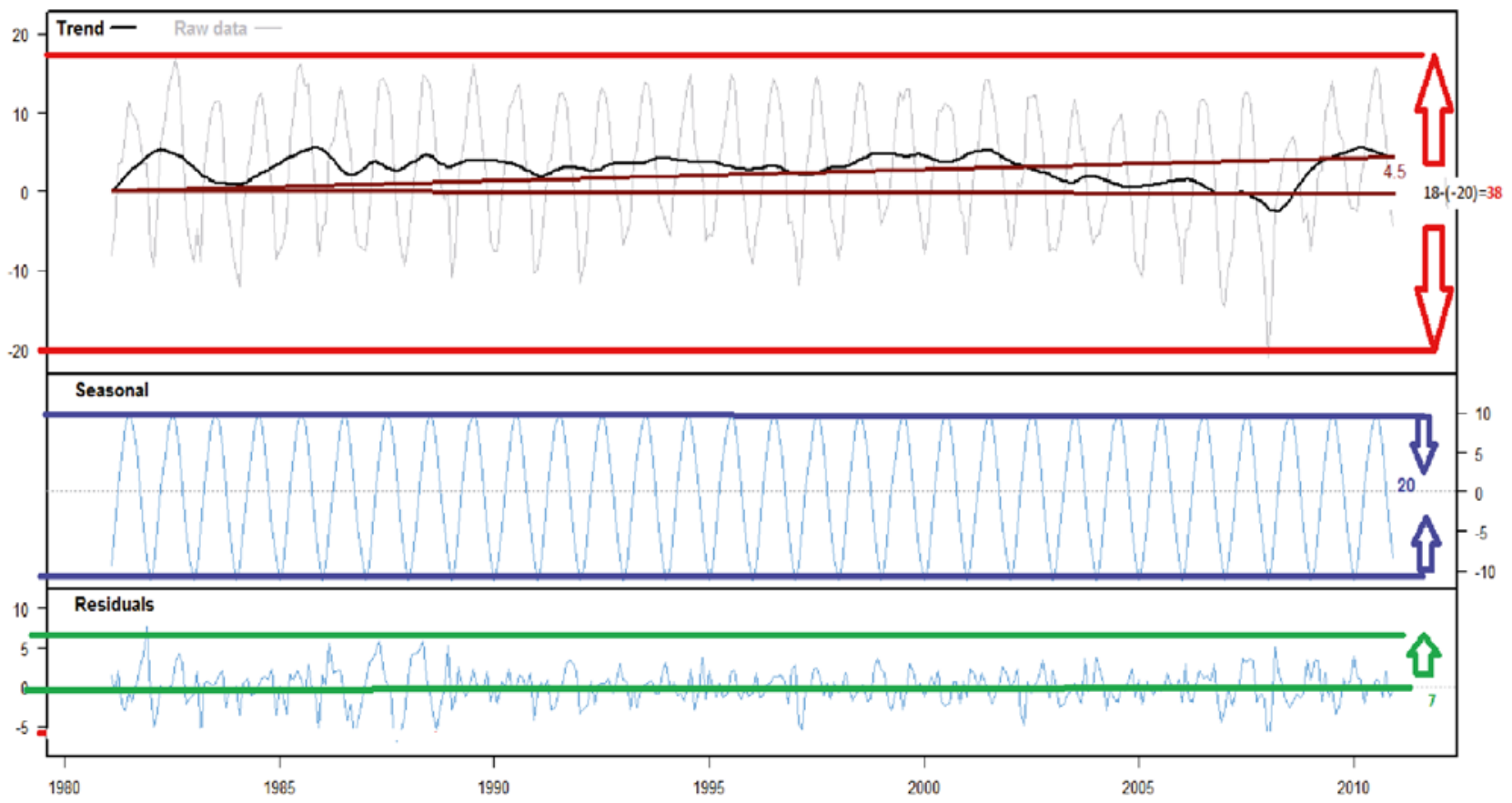

Fig. 3. Minimum temperature and time series components evaluation $\left({ }^{\circ} \mathrm{C}\right)$.
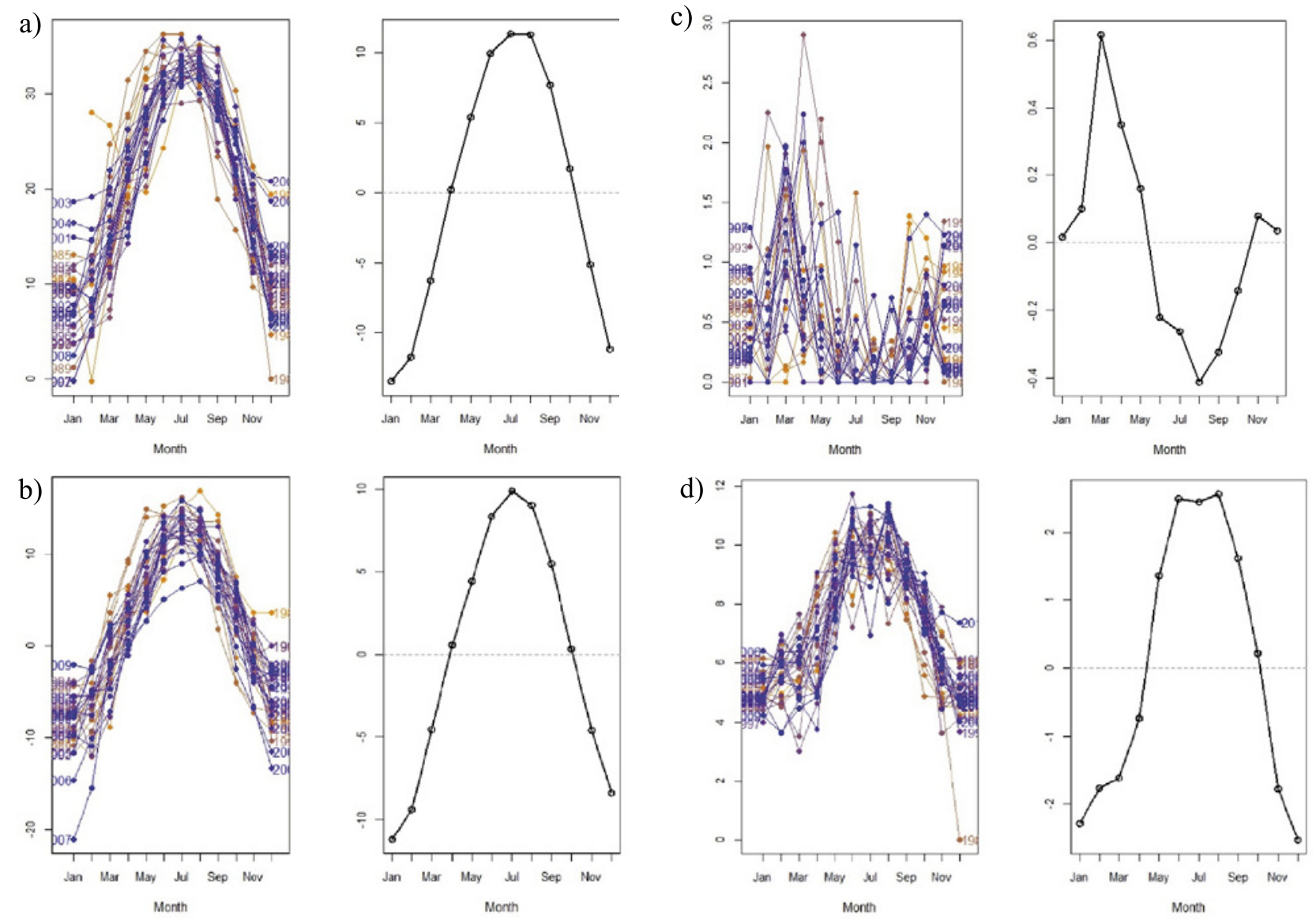

Fig. 4. Effects of the seasonal cycle (left) and the estimated seasonal effect (right) for a) maximum temperature, b) minimum temperature, and c) rainfall and d) sunshine parameters. 


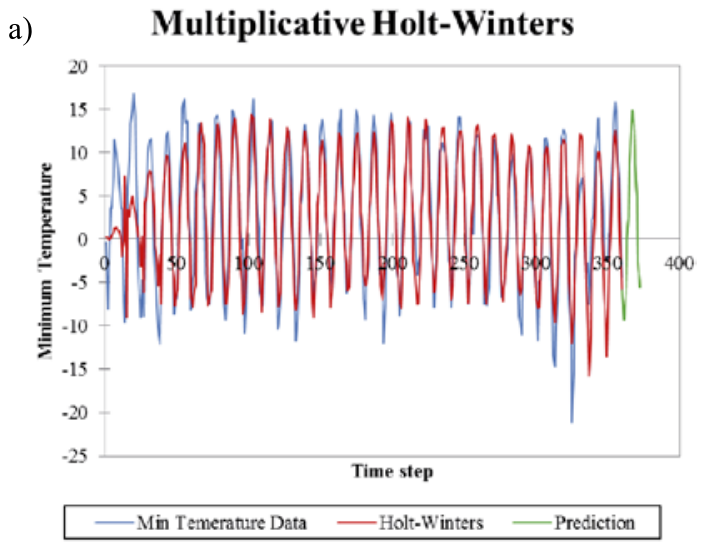

b)

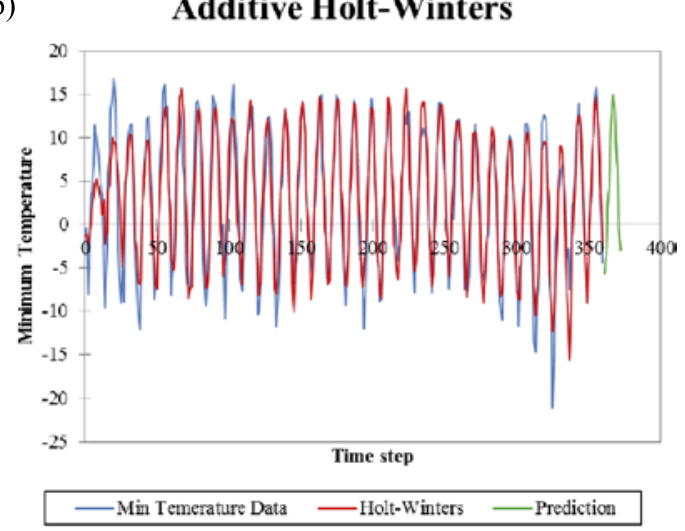

c) Multiplicative Holt-Winters

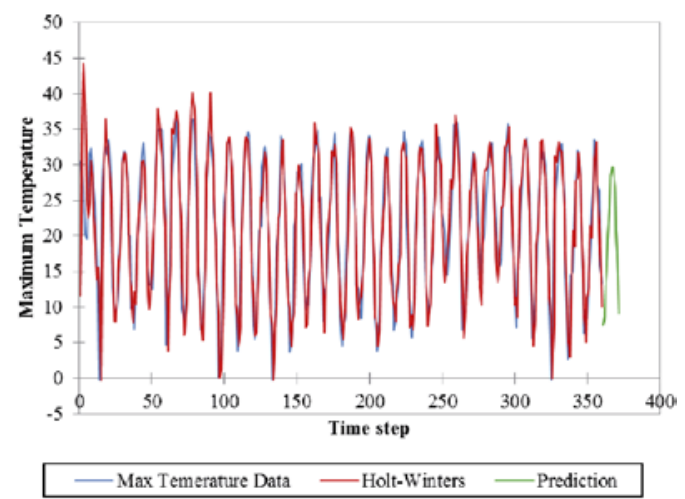

d)

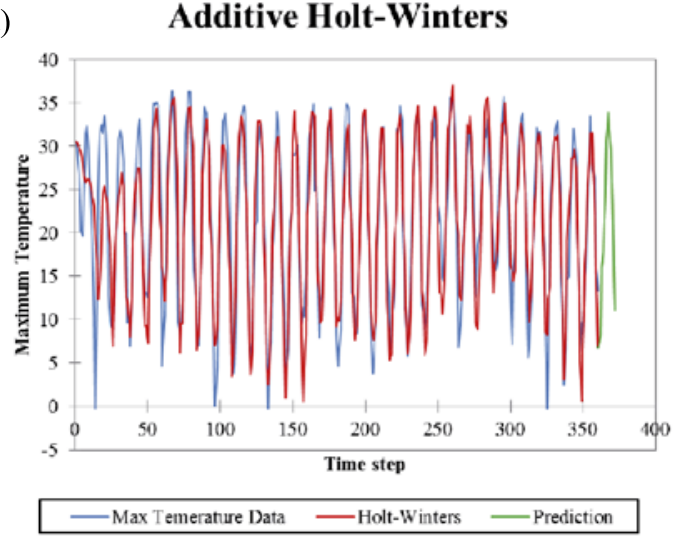

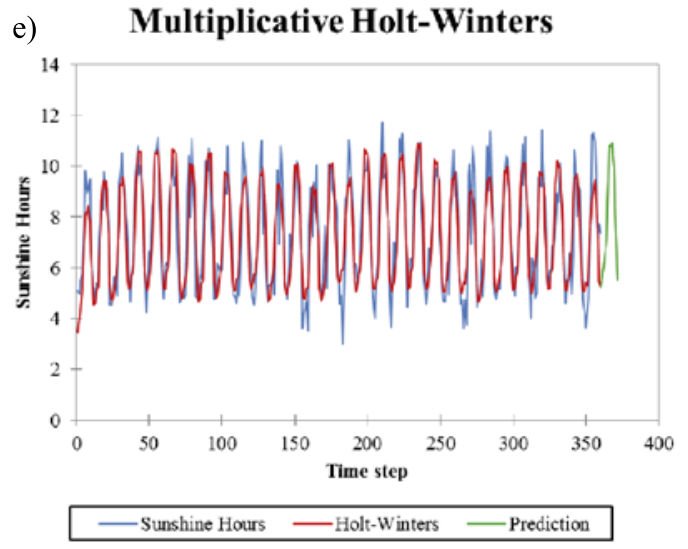

f)

Additive Holt-Winters

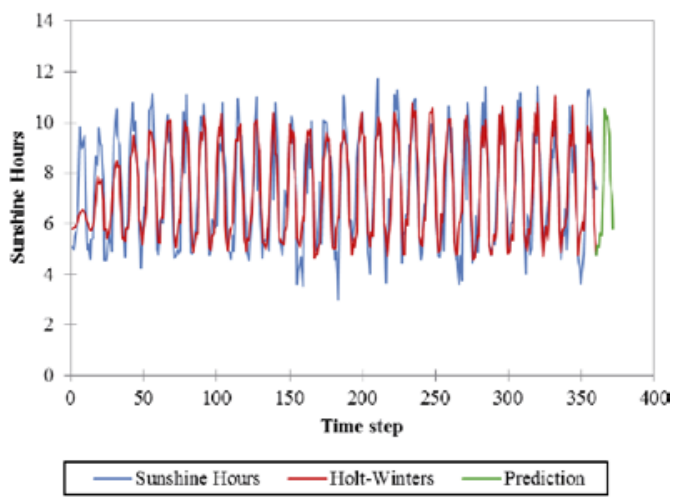

g) Multiplicative Holt-Winters
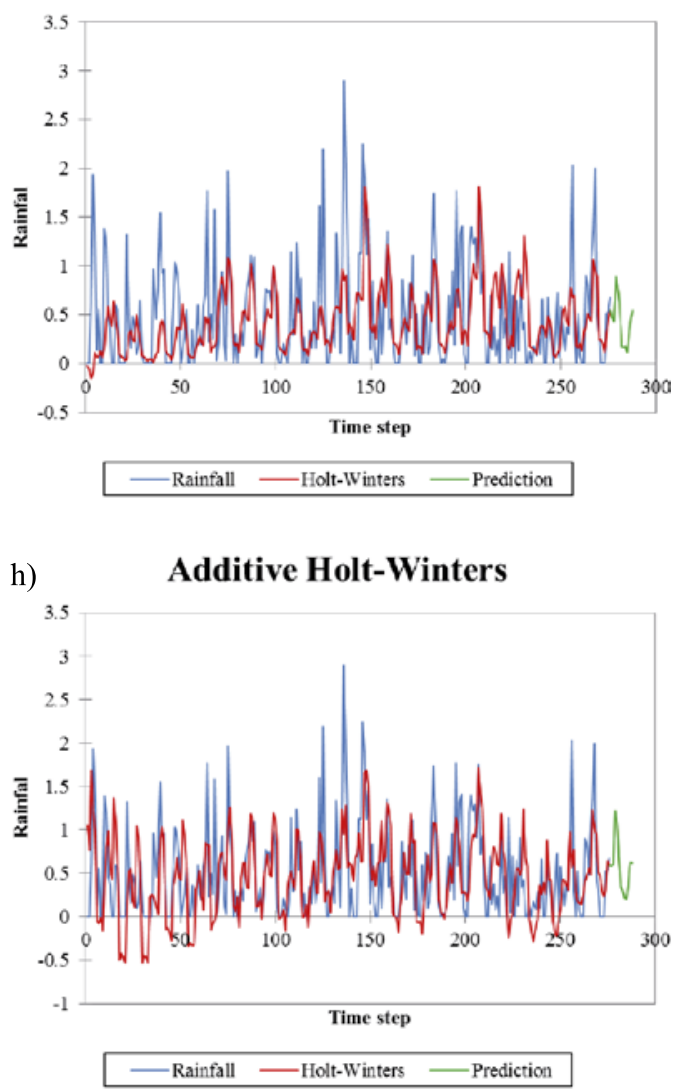

Fig. 5. Monthly forecast of the a-b) minimum temperature, c-d), maximum temperature, e-f) sunshine hours and g-h) rainfall obtained from multiplicative Holt-Winters and additive Holt-Winters. 


$$
b_{0}=\frac{\left\{\sum_{t=1}^{s} y_{t} / s\right\}-\left\{\sum_{t=s+1}^{2 s} y_{t} / s\right\}}{s}
$$

Finally, the amount of seasonal index starting can be calculated after trend adjusting.

$$
\begin{gathered}
c_{0}=\frac{\left\{y_{k}-(k-1) b_{0} / 2\right\}}{m_{0}}(\text { multiplicative) } \\
c_{0}=y_{k}-\left\{m_{0}+(k-1) b_{0} / 2\right\} \text { (additive) }
\end{gathered}
$$

...where $\mathrm{k}=1,2 \ldots$ Obviously this will lead to s separate values for $c_{0}$, which is the basic requirement to reach the initial seasonal pattern.

Most of the smoothing parameters are chosen between 0.02 and 0.2 . It is possible to estimate smoothing parameters by minimizing the mean average percentage errors (Eq. 15). Once the one-step-ahead prediction is created, the percentage error $P E_{t}$ of the real and predicted data is obtained. Afterward, MAPE, which is the average of obtained $P E_{t}$, is minimized (Eq. 14).

$$
M A P E=\frac{1}{n} \sum_{t=1}^{n}\left|P E_{t}\right|
$$

$$
\text { minimize MAPE; }
$$

Constrained to:

$$
\begin{gathered}
0 \leq \alpha, \beta, \gamma \leq 1 \\
R M S E=\frac{\sqrt{\sum_{i=1}^{n}\left(P_{i}-\hat{P}_{i}\right)^{2}}}{n}
\end{gathered}
$$

...where $P_{i}$ is observational data, $\hat{P}_{i}$ is computational data (predicted), and is the number of predicted data.

\section{Results and Discussion}

Modeling of many hydrological processes results from numerous interactions that create complex systems; it's a difficult yet important task. Time series modeling to generate data and forecast hydrological variables is an important step in the design and sensitivity analysis of water resources. Usually for analyzing time series, changes that result from trend, seasonal variations and irregular variations are taken into account.

Trend: It is called natural trend of time series in long-term. In this case, the fluctuations of the time series are negligible and the overall view can be considered. Therefore, by studying data from a long period a general idea of a phenomenon's behavior can be obtained, which can help in predicting future behavior.

Seasonal changes: changes that occur during a short interval. These changes are related to factors that operate in a regular and cyclical manner over a period of less than one year. For instance, if time series observations are recorded monthly, seasonal changes in time series are available on a monthly basis.

Irregular changes: These changes are completely random and result from unpredictable factors, which act in an irregular manner. These changes do not show a specific plan and occurring time is not regular; this is because it is called irregular changes. These changes have short-term effects, but occasionally they are frequent enough to cause periodic or other changes. Fig. 2 shows graphs of decomposition of maximum temperature a), minimum temperature b), rainfall c), total sunshine hours d), the separation process, seasonal variations and irregular variations (random). As can be seen, irregularities in rainfall data are far more distinctive.

To evaluate the time series components such as trend component, seasonal component and residual component, for example, for minimum temperature data

\begin{tabular}{|c|c|c|c|c|c|c|c|c|c|c|c|c|}
\hline & \multicolumn{3}{|c|}{ Rainfall } & \multicolumn{3}{|c|}{ Sunshine Hours } & \multicolumn{3}{|c|}{ Minimum Temperature } & \multicolumn{3}{|c|}{ Maximum Temperature } \\
\hline & $\alpha$ & $\beta$ & $\gamma$ & $\alpha$ & $\beta$ & $\gamma$ & $\alpha$ & $\beta$ & $\gamma$ & $\alpha$ & $\beta$ & $\gamma$ \\
\hline Additive & 0.15 & 0.02 & 0.13 & 0.02 & 0.00 & 0.38 & 0.13 & 0.04 & 0.60 & 0.13 & 0.00 & 0.43 \\
\hline Multiplicative & 0.14 & 0.01 & 0.00 & 0.14 & 0.00 & 0.00 & 0.08 & 0.03 & 0.00 & 0.97 & 0.00 & 0.00 \\
\hline
\end{tabular}
we have:

- Total Variation: $18-(-20)=38$.

- Trend Component: $4.5 / 38=12 \%$.

Table 2. MAPE and RMSE values for additive and multiplicative models.

\begin{tabular}{|c|c|c|c|c|c|c|c|c|}
\hline \multirow{2}{*}{} & \multicolumn{2}{|c|}{ Rainfall } & \multicolumn{2}{c|}{ Sunshine Hours } & \multicolumn{2}{c|}{ Minimum Temperature } & \multicolumn{2}{c|}{ Maximum Temperature } \\
\cline { 2 - 10 } & MAPE & RMSE & MAPE & RMSE & MAPE & RMSE & MAPE & RMSE \\
\hline Additive & 0.38 & 0.496 & 0.88 & 1.29 & 2.4 & 3.58 & 3.13 & 4.84 \\
\hline Multiplicative & 0.35 & 0.490 & 0.79 & 1.01 & 2.75 & 3.67 & 2.83 & 3.99 \\
\hline
\end{tabular}

Table 3. Optimized values of triple exponential smoothing parameters. 
a)

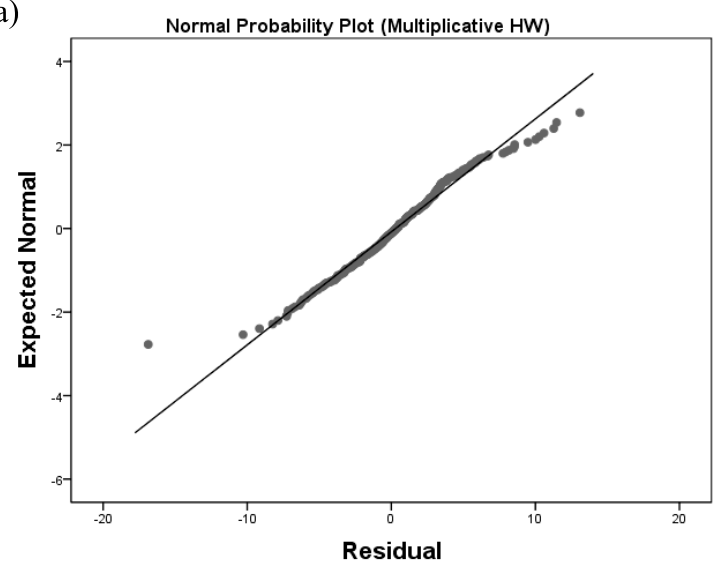

b)

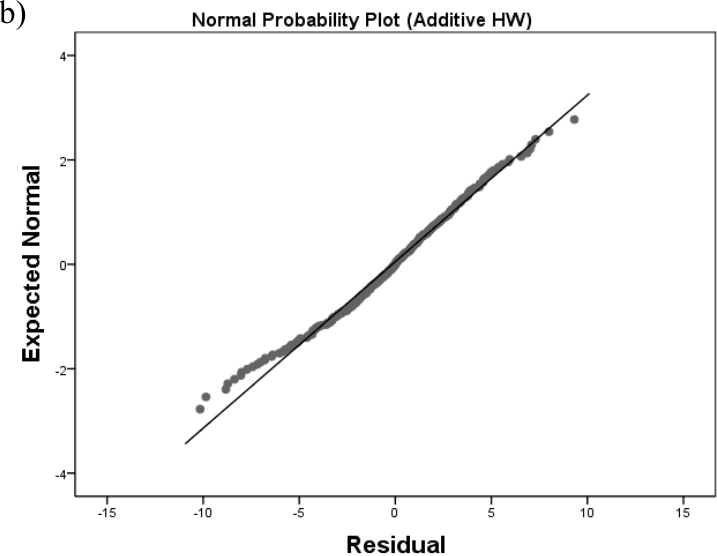

c)

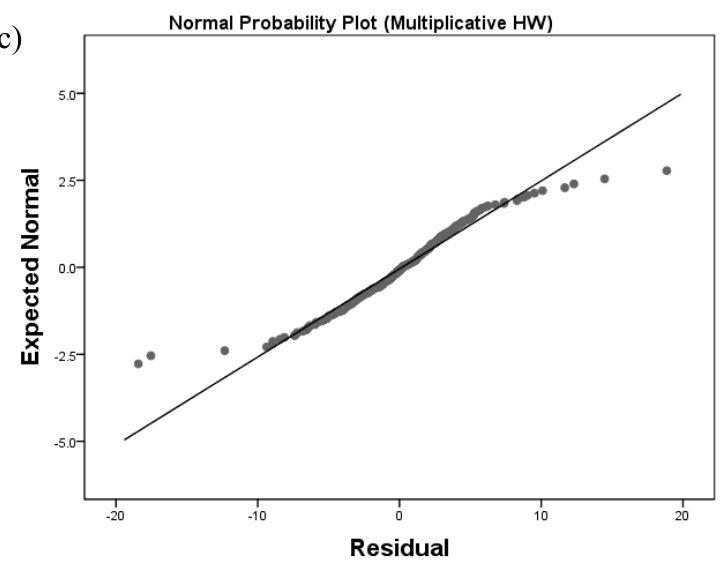

d)

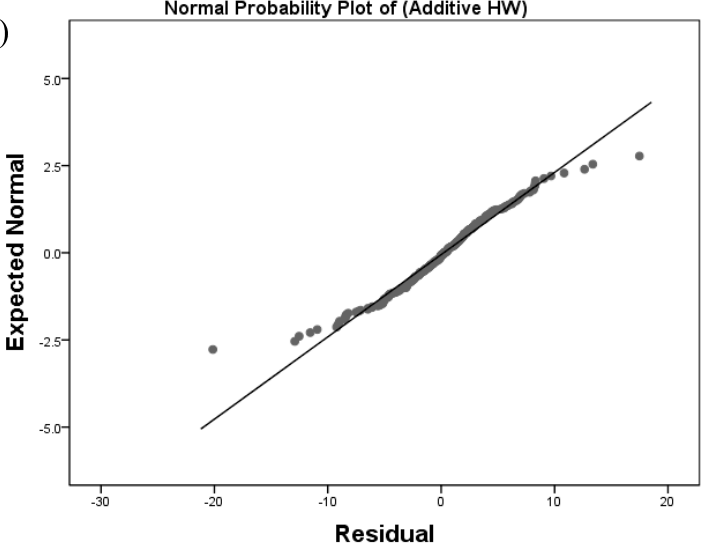

e)

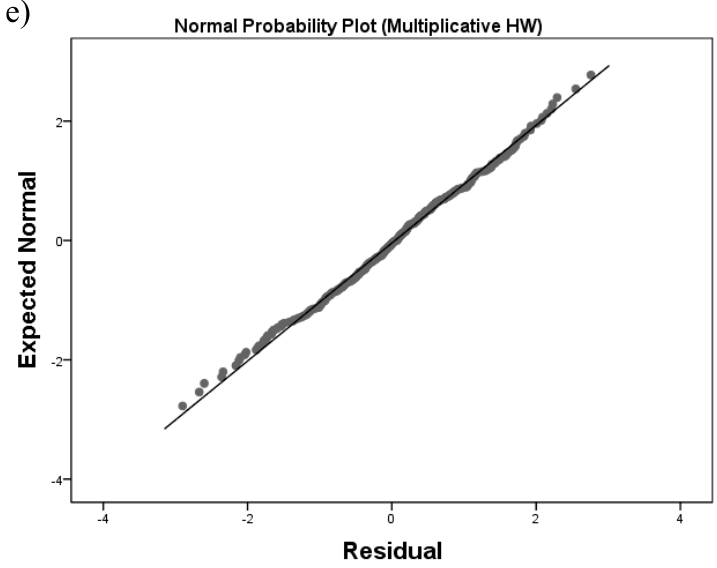

f)
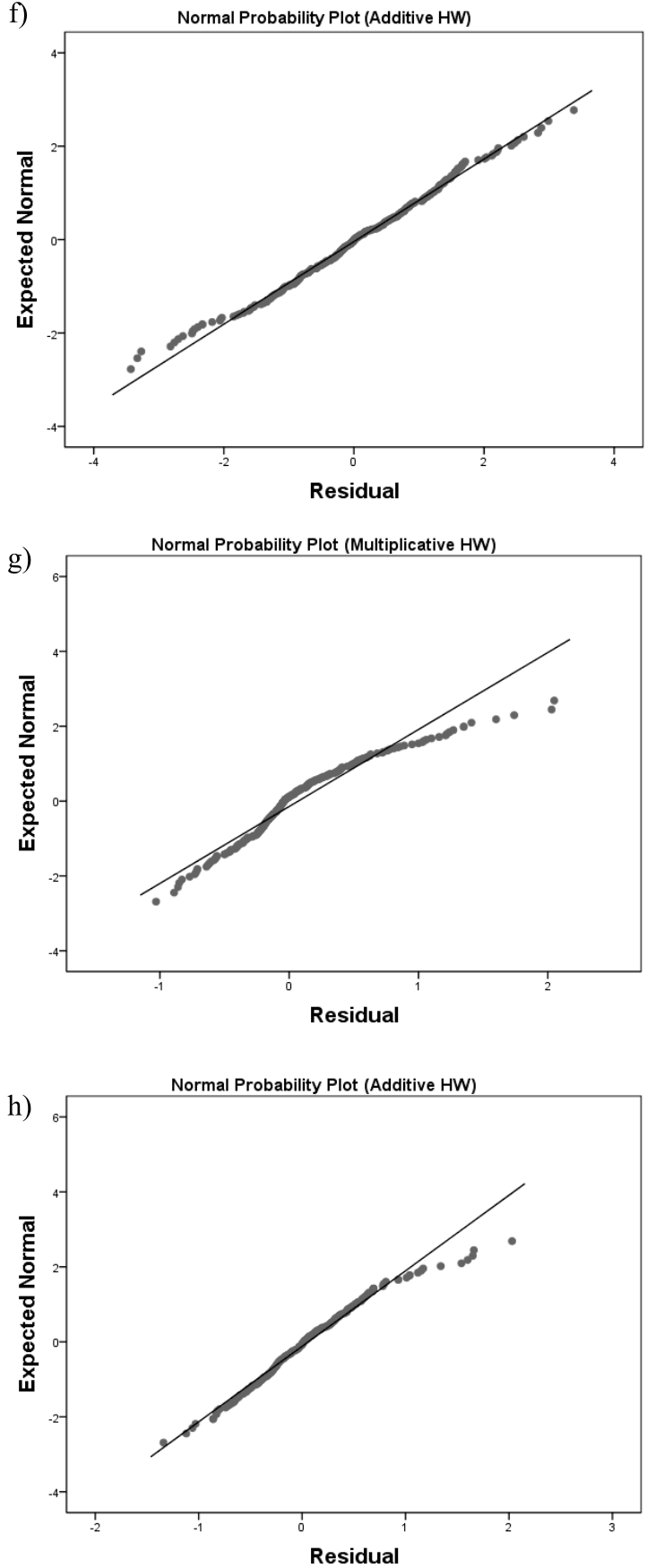

Fig. 6. Normal probability plot of the residuals: a-b) minimum temperature $\left.\left({ }^{\circ} \mathrm{C}\right), \mathrm{c}-\mathrm{d}\right)$ maximum temperature $\left({ }^{\circ} \mathrm{C}\right)$, e-f) sunshine hours (average hours per day), g-h) rainfall $(\mathrm{cm})$. 
- Seasonal component: $20 / 38=53 \%$.

- Residual component: $7 / 38=18 \%$.

Fig. 4 shows the effects of the seasonal cycle (left) and the estimated seasonal effect (right) for the parameters of temperature a), minimum temperature b), rainfall c), and total sunshine hours d). These images show that if there is a long-term process, they can be spread in such a manner. Also, it can be seen that there is a partly steady pattern for temperature, minimum temperature and total sunshine hours. However, the seasonality pattern oscillates a bit erratically for rainfall historical data.

Fig. 5 shows the monthly forecast for maximum temperature a), minimum temperature b), rainfall c), and total sunshine hours d) that are obtained from both the multiplicative and additive Holt-Winters model; red lines are the one-step-ahead forecast using Holt-Winters model. Green line shows one-year predicted values for related data.

The three aforementioned parameters of triple exponential smoothing model should be optimized to get better convergence of the observed and estimated data (Table 1). In this study nonlinear generalized reduced gradient algorithm (GRG nonlinear) is used to optimize the objective function that is to minimize the MAPE or RMSE. The only constraint of the problem is to limit the value of all three parameters between zero and one. The results are shown in Tables 2 and 3. According to Table 2, it can be seen that in the case of rainfall and sunshine, the multiplicative model shows better results. Although the optimized values of MAPE in both models are relatively close, the output shows significant differences in predicted values (Fig. 5).

\section{Validity of the Model}

Measuring validity of every hydrological model is essential to show the goodness of the fit. Regarding time series model, if the residuals (difference between actual and fitted data) are random, i.e., they are normally distributed, it can be deduced that the model is powerful enough to model the cyclic, seasonality and trend patterns of each climate parameter. Fig. 6 presents the normal probability plot of the residuals, which depict the colonization of residuals around the normal line. As can be seen, almost all the residuals are approximately normal.

As a result, except for the sunshine hours model (in both additive and multiplicative methods) in which residuals show normal distribution, the other models seem incapable of fitting the actual data. However, from the normal probability plots one can infer that all residuals are approximately normal.

\section{Conclusions}

In this study the additive and multiplicative HW model is used to predict the four climate parameters for one consecutive year. Best parameters $\alpha, \beta$ and $\gamma$ are selected based on MAPE values. Because of the variant nature of meteorological time series, these parameters should adapt to this change, and therefore their values are optimized. It is observed that with adequate range of data a model can adapt better and tend to adjust to the most recently observed data. However, in this study the multiplicative form of HW model shows better accuracy and adjusts itself relatively well to the observed data.

The optimization procedure, however, may seem to have a major role in convergence of the model. Since one algorithm is used in this study, it is difficult to claim the accuracy of this procedure. Therefore, we recommend that several optimization algorithms be used in order to get better results.

\section{Acknowledgements}

The authors would like to thank the Iran Meteorological Organization and the National Natural Science Foundation of China (grant No. 51679042) for the financial support to conduct our research and for technical assistance. The author would also like to emphasize that all the data used in this research were obtained by the authors through monitoring stations and field measurements.

\section{Conflict of Interest}

The authors declare no conflict of interest.

\section{References}

1. COOK C.N., INAYATULLAH S., BURGMAN M.A., SUTHERLAND W.J., WINTLE B.A. Strategic foresight: how planning for the unpredictable can improve environmental decision-making. Trends in ecology \&evolution. 29 (9), 531, 2014.

2. HARRISON M.T., TARDIEU .F, DONG Z., MESSINA C.D., HAMMER G.L. Characterizing drought stress and trait influence on maize yield under current and future conditions. Global change biology. 20 (3), 867, 2014.

3. BERNAL J.L., CUMMINS S., GASPARRINI A. Interrupted time series regression for the evaluation of public health interventions: a tutorial. International journal of epidemiology. 46 (1), 348, 2017.

4. FAUST K., LAHTI L., GONZE D., DE VOS W.M., RAES J. Metagenomics meets time series analysis: unraveling microbial community dynamics. Current opinion in microbiology. 25, 56, 2015.

5. GOCHEVA-ILIEVA S.G., IVANOV A.V., VOYNIKOVA D.S., BOYADZHIEV D.T. Time series analysis and forecasting for air pollution in small urban area: an SARIMA and factor analysis approach. Stochastic environmental research and risk assessment. 28 (4), 1045, 2014. 
6. MONTGOMERY D.C., JENNINGS C.L., KULAHCI M. Introduction to time series analysis and forecasting. John Wiley \& Sons. 2015.

7. SWITANEK M. Forecasting Climate and Water Resources in the Context of Natural Variability and Climate Change. 2013.

8. SAYEMUZZAMAN M., JHA M.K. Seasonal and annual precipitation time series trend analysis in North Carolina, United States. Atmospheric Research. 137, 183, 2014.

9. BOX G.E., JENKINS G.M., REINSEL G.C., LJUNG G.M. Time series analysis: forecasting and control. John Wiley \& Sons. 2015.

10. FEIDAS H., NOULOPOULOU C., MAKROGIANNIS T., BORA-SENTA E. Trend analysis of precipitation time series in Greece and their relationship with circulation using surface and satellite data: 1955-2001. Theoretical and Applied Climatology. 87 (1-4), 155, 2007.

11. VALIPOUR M. How much meteorological information is necessary to achieve reliable accuracy for rainfall estimations?, Agriculture. 6 (4), 53, 2016.

12. LIN B., CHEN X., YAO H., CHEN Y., LIU M., GAO L., JAMES A. Analyses of landuse change impacts on catchment runoff using different time indicators based on SWAT model. Ecological Indicators, 58, 55, 2015.

13. NASTOS P., PALIATSOS A., KOUKOULETSOS K., LARISSI I., MOUSTRIS K. Artificial neural networks modeling for forecasting the maximum daily total precipitation at Athens, Greece. Atmospheric Research. 144, 141, 2014

14. ASHRAF VAGHEFI S., MOUSAVI S., ABBASPOUR K., SRINIVASAN R., YANG H. Analyses of the impact of climate change on water resources components, drought and wheat yield in semiarid regions: Karkheh River Basin in Iran. Hydrological processes. 28 (4), 2018, 2014.

15. HUANG D., HAACK R.A., ZHANG R. Does global warming increase establishment rates of invasive alien species? A centurial time series analysis. PLoS One. 6 (9), e24733, 2011

16. KUSANGAYA S., WARBURTON M.L., VAN GARDEREN E.A., JEWITT G.P. Impacts of climate change on water resources in southern Africa: A review. Physics and Chemistry of the Earth. Parts A/B/C, 67, 47, 2014.

17. LI T., HASEGAWA T., YIN X., ZHU Y., BOOTE K., ADAM M., BREGAGLIO S., BUIS S., CONFALONIERI R., FUMOTO T., GAYDON D., MARCAIDA M 3RD, NAKAGAWA H., ORIOL P., RUANE A.C., RUGET F., SINGH B., SINGH U., TANG L., TAO F., WILKENS P., YOSHIDA H., ZHANG Z., BOUMAN B. Uncertainties in predicting rice yield by current crop models under a wide range of climatic conditions. Global Change Biology. 21 (3), 1328, 2015

18. MAHATO A. Climate change and its impact on agriculture. International Journal of Scientific and Research Publications. 4 (4), 1, 2014.

19. TREBICKI P., NANCARROW N., COLE E., BOSQUEPÉREZ N.A., CONSTABLE F.E., FREEMAN A.J., RODONI B., YEN A.L., LUCK J.E., FITZGERALD G.J. Virus disease in wheat predicted to increase with a changing climate. Global change biology. 21 (9), 3511, 2015.

20. SVOBODOVÁ E., TRNKA M., DUBROVSKY M., SEMERADOVA D., EITZINGER J., STEPANEK P., ZALUD Z. Determination of areas with the most significant shift in persistence of pests in Europe under climate change. Pest management science. 70 (5), 708,
2014.

21. FENG H., DUAN G., ZHANG R., ZHANG W. Time series analysis of hand-foot-mouth disease hospitalization in Zhengzhou: establishment of forecasting models using climate variables as predictors. PLoS One. 9 (1), e87916, 2014.

22. LI F., ZHANG Y., XU Z., LIU C., ZHOU Y., LIU W. Runoff predictions in ungauged catchments in southeast Tibetan Plateau. Journal of Hydrology. 5 (11), 28, 2014.

23. KHADKA D., BABEL M.S., SHRESTHA S., TRIPATHI N.K. Climate change impact on glacier and snow melt and runoff in Tamakoshi basin in the Hindu Kush Himalayan (HKH) region. Journal of Hydrology. 5 (11), 49, 2014.

24. ZHANG F., ZHANG H., HAGEN S.C., YE M., WANG D., GUI D., ZENG C., TIAN L., LIU J. Snow cover and runoff modelling in a high mountain catchment with scarce data: effects of temperature and precipitation parameters. Hydrological processes. 29 (1), 52, 2015.

25. JAHANBANI H., EL-SHAFIE A.H. Application of artificial neural network in estimating monthly time series reference evapotranspiration with minimum and maximum temperatures. Paddy and Water Environment. 9 (2), 207, 2011.

26. DEO R.C., ŞAHIN M. Application of the artificial neural network model for prediction of monthly standardized precipitation and evapotranspiration index using hydrometeorological parameters and climate indices in eastern Australia. Atmospheric research. 161, 65, 2015.

27. FALAMARZI Y., PALIZDAN N., HUANG Y.F., LEE T.S. Estimating evapotranspiration from temperature and wind speed data using artificial and wavelet neural networks (WNNs). Agricultural Water Management. 140, 26, 2014.

28. VALIPOUR M. Temperature analysis of reference evapotranspiration models. Meteorological Applications. 22 (3), 385, 2015.

29. SHUKLA S., SAFEEQ M., AGHAKOUCHAK A., GUAN K., FUNK C. Temperature impacts on the water year 2014 drought in California. Geophysical Research Letters. 42 (11), 4384, 2015.

30. AGHAKOUCHAK A., CHENG L., MAZDIYASNI O., FARAHMAND A. Global warming and changes in risk of concurrent climate extremes: Insights from the 2014 California drought. Geophysical Research Letters. 41 (24), 8847, 2014.

31. NICHOLLS N. The changing nature of Australian droughts. Climatic Change. 63 (3), 323, 2004.

32. YANG K., WU H., QIN J., LIN C., TANG W., CHEN Y. Recent climate changes over the Tibetan Plateau and their impacts on energy and water cycle: A review. Global and Planetary Change. 112, 79, 2014.

33. QAZI A., FAYAZ H., WADI A., RAJ R.G., RAHIM N., KHAN W.A. The artificial neural network for solar radiation prediction and designing solar systems: a systematic literature review. Journal of Cleaner Production. 104, 1, 2015.

34. SHAMIM M., REMESAN R., BRAY M., HAN D. An improved technique for global solar radiation estimation using numerical weather prediction. Journal of Atmospheric and Solar-Terrestrial Physics. 129, 13, 2015.

35. ERNAKOVICH J.G., HOPPING K.A., BERDANIER A.B., SIMPSON R.T., KACHERGIS E.J., STELTZER H., WALLENSTEIN M.D. Predicted responses of arctic and alpine ecosystems to altered seasonality under climate change. Global Change Biology. 20 (10), 3256, 2014.

36. BADESCU V. Modeling solar radiation at the earth's surface. Springer. 2014. 
37. PEREIRA L.S., ALLEN R.G., SMITH M., RAES D. Crop evapotranspiration estimation with FAO56: Past and future. Agricultural Water Management. 147, 4, 2015.

38. RAMEDANI Z., OMID M., KEYHANI A., SHAMSHIRBAND S., KHOSHNEVISAN B. Potential of radial basis function based support vector regression for global solar radiation prediction. Renewable and Sustainable Energy Reviews. 39, 1005, 2014.

39. KHORASANIZADEH H., MOHAMMADI K., MOSTAFAEIPOUR A. Establishing a diffuse solar radiation model for determining the optimum tilt angle of solar surfaces in Tabass, Iran. Energy conversion and management. 78, 805, 2014.

40. MCKERCHAR A., DELLEUR J. Application of seasonal parametric linear stochastic models to monthly flow data. Water Resources Research. 10 (2), 246, 1974.

41. TIBA C., FRAIDENRAICH N. Analysis of monthly time series of solar radiation and sunshine hours in tropical climates. Renewable energy. 29 (7), 1147, 2004.

42. KOMORNÍK J., KOMORNÍKOVÁ M., MESIAR R., SZÖKEOVÁ D., SZOLGAY J. Comparison of forecasting performance of nonlinear models of hydrological time series. Physics and Chemistry of the Earth, Parts A/B/C. 31 (18), 1127, 2006.

43. CHATTOPADHYAY S. Feed forward Artificial Neural Network model to predict the average summer-monsoon rainfall in India. Acta Geophysica. 55 (3), 369, 2007.

44. DAMLE C., YALCIN A. Flood prediction using time series data mining. Journal of Hydrology. 333 (2), 305, 2007.

45. SUNYER M., MADSEN H., ANG P. A comparison of different regional climate models and statistical downscaling methods for extreme rainfall estimation under climate change. Atmospheric Research. 103, 119, 2012.

46. NOORI M., ZARGHAMI M., SHARIFI M.B., HEYDARI M. Utilization of LARS-WG Model for Modelling of Meteorological Parameters in Golestan Province of Iran. Journal of River Engineering. 1, 2013.

47. VIOLA F., CARACCIOLO D., PUMO D., NOTO L., LOGGIA G. Future Climate Forcings and Olive Yield in a Mediterranean Orchard. Water. 6 (6), 1562, 2014.

48. KILSBY C., JONES P., BURTON A., FORD A.C., FOWLER H.J., HARPHAM C., JAMES P., SMITH A.,
WILBY R.L. A daily weather generator for use in climate change studies. Environmental Modelling \& Software. 22 (12), 1705, 2007.

49. FATHELRAHMAN E., DAVIES A., DAVIES S., PRITCHETT J. Assessing Climate Change Impacts on Water Resources and Colorado Agriculture Using an Equilibrium Displacement Mathematical Programming Model. Water. 6 (6), 1745, 2014.

50. GAIN A.K., GIUPPONI C., RENAUD F.G. Climate Change Adaptation and Vulnerability Assessment of Water Resources Systems in Developing Countries: A Generalized Framework and a Feasibility Study in Bangladesh. Water. 4 (2), 345, 2012.

51. CONTE G., BOLOGNESI A., BRAGALLI C, BRANCHINI S., CARLI A.D., LENZI C., MASI F., MASSARUTTO A., POLLASTRI M., PRINCIPI I. Innovative Urban Water Management as a Climate Change Adaptation Strategy: Results from the Implementation of the Project "Water Against Climate Change (WATACLIC)". Water. 4 (4), 1025, 2012.

52. ZACHARIADIS T. Residential Water Scarcity in Cyprus: Impact of Climate Change and Policy Options. Water. 2 (4), 788, 2010.

53. BANGASH R.F., PASSUELLO A., SANCHEZCANALES M., TERRADO M., LÓPEZ A., ELORZA F.J., ZIV G., ACUÑA V., SCHUHMACHER M. Ecosystem services in Mediterranean river basin: climate change impact on water provisioning and erosion control. Science of the Total Environment. 458, 246, 2013.

54. MANFREDA S., CAYLOR K. On the Vulnerability of Water Limited Ecosystems to Climate Change. Water. 5 (2), 819, 2013.

55. DAVIES P.M. Climate change implications for river restoration in global biodiversity hotspots. Restoration Ecology. 18 (3), 261, 2010.

56. ROCHDANE S., REICHERT B., MESSOULI M., BABQIQI A., KHEBIZA M.Y. Climate Change Impacts on Water Supply and Demand in Rheraya Watershed (Morocco), with Potential Adaptation Strategies. Water. 4 (1), 28, 2012.

57. CHATFIELD C., YAR M. Holt-Winters forecasting: some practical issues. The Statistician. 129, 1988. 
